\title{
CROSS-CULTURAL VARIATION IN THE EXPRESSION OF PERSUASIVE POWER IN THE GENRE OF TECHNICAL MANUALS: THE CASE OF DIRECTIVES
}

\author{
Renata Povolná
}

\begin{abstract}
The paper provides a cross-cultural analysis of selected linguistic realizations of persuasion in technical manuals as typical representatives of technical discourse. It aims to identify differences and similarities between the ways persuasive power is expressed in this type of specialized discourse in English and Czech L1 texts. The data comprises manuals to various technical devices and amounts to slightly more than 200,000 words. This specialized corpus (15 manuals in English and 15 in Czech) is assumed to enable the comparison of the ways in which technical communicators express persuasion. The investigation, which is conducted from the perspectives of corpus analysis and discourse analysis, focuses on the ways in which the interactive and dynamic process of persuasion is explicitly manifested: 1. directly (i.e. using directives expressed by imperatives of full verbs, modals of obligation, necessity, prohibition, and predicative adjectives expressing the writer's judgement of the necessity to perform an action) and 2. indirectly (i.e. using other language means than directives, such as other modals than those related to obligation, necessity or prohibition, conditional clauses, rhetorical questions). The findings are expected to be relevant and applicable in the education domain to raise technical writers' awareness of directives as useful persuasive strategies suitable for the production of effective well-written technical manuals since their quality including the appropriate degree of persuasiveness can influence prospective consumers to make a purchase of a particular technical device.
\end{abstract}

\section{Keywords}

cross-cultural analysis, technical discourse (TD), technical manuals (TMs), persuasion, persuasive power, persuasive strategies, directives, imperatives, modal verbs, predicative adjectives

\section{Introduction}

With the use of English as an international lingua franca in all global communication it has become indispensable to study and compare rhetorical strategies used in Anglophone and non-Anglophone cultures in order to enhance effective intercultural communication, including communication in technical settings. The study of rhetorical strategies naturally includes persuasive strategies since persuasion has always been an integral part of all human communication 
(cf. Miller 1980, Lakoff 2000, Perloff 2010) and "learning more about persuasion is learning more about human nature" (Virtanen \& Halmari 2005: 4-5). Accordingly, persuasion is understood here as "all linguistic behaviour that attempts to either change the thinking or behavior of an audience, or to strengthen its beliefs, should the audience already agree" (ibid.). The audience, even if invisible or implied, also contributes to the process of persuasion and, in fact, it is the audience that determines what kind of persuasion is most effective. Consequently, persuasion is necessarily viewed as an inherently intentional, dynamic and interactive process affected by the situational and socio-cultural context and involving various rhetorical strategies and "those linguistic choices that aim at changing or affecting the behavior of others" (ibid.: 4).

Persuasion is traditionally related to the three classic Aristotelian types of appeal to the audience (cf. Virtanen \& Halmari 2005: 5): 1. ethos, i.e. the ethical voice of the persuader, the conveyed message of their reliability, authority and competence (realized in the form of direct appeal to the reader, sharing personal experience, claiming common ground and building speaker credibility on the basis of authority and expertise); 2. pathos, i.e. the emotional appeal to the audience (only marginal in specialized discourse such as the genre of technical manuals); and 3. logos, i.e. the appeal to the rationality of the audience (realized in the form of causality mechanisms, intertextual and intratextual reference to facts and sources, presenting the current/future state as a natural consequence of the past, providing evidence and exemplification) (cf. e.g. Virtanen \& Halmari 2005, Dontcheva-Navratilova 2011). In technical discourse, the appeal to the rationality of the audience (i.e. logos) and the appeal to the reliability and competence of the persuader (i.e. ethos) tend to be equally important Aristotelian types of appeal, thus representing what can be labelled as a logos-ethos interface. In other words, the concrete linguistic manifestations of persuasion used by the technical communicator equally contribute to logos and ethos. In line with Dontcheva-Navratilova (2018: 232), persuasion can be postulated as "a function of the assessment of the trustworthiness of what is communicated [...] carried out on the basis of two types of epistemic vigilance processes: (i) assessment of the credibility of the source and (ii) assessment of the reliability of the content conveyed".

Various persuasive strategies can be adopted by speakers or writers of a language to present their ideas and enhance their arguments in order to persuade hearers or readers to behave as required and expected. These strategies entail certain broader categories of persuasive features, such as stance and engagement, dialogicity and various types of intertextuality (cf. e.g. Adam 2017, DontchevaNavratilova 2018); these can be manifested explicitly by speakers or writers in 
certain linguistic means such as imperatives, modal verbs, evaluative adjectives, questions, or they can remain implicit in the language behaviour of speakers or writers (e.g. emotions, humour) (cf. e.g. Virtanen \& Halmari 2005: 14). Unlike implicit persuasive strategies which are often associated with religious discourse, for example (cf. Adam 2017), the explicit expression of the persuasive force is typical of technical discourse analysed in this article. It is demonstrated either directly in concrete linguistic means such as directives (e.g. obligation modals), or indirectly through the use of other means than directives, i.e. those which, thanks to the context, also express the directive force although their primary function is not to make someone perform an action. It must be noted here that both direct and indirect ways of expression are supported by some visual means, such as diagrams, charts, graphs, icons, images and tables, which also clearly foster the overall persuasiveness and effectiveness of the language of technical manuals.

The present study focuses on linguistic realizations of directives as one of the most important direct ways of the expression of the persuasive power of the technical writer over the reader with the aim to describe and explain the differences and similarities between English L1 and Czech L1 texts, represented by English and Czech technical manuals. Accordingly, the study undertakes to discover which linguistic realizations of directives are applied in the English in comparison with the Czech TMs in my data, the distribution of three main direct ways in which directives are expressed (i.e. imperatives of full verbs, modal verbs expressing obligation, necessity and prohibition, and predicative adjectives expressing the writer's judgement of the necessity to perform an action), and, finally, whether there are any indirect ways in which directives can also be expressed in TMs.

\section{Technical discourse and technical manuals}

Technical discourse, also called communication of technology or technical communication, mediates the dissemination of knowledge and latest technological developments to both expert and lay audiences. In this article it is represented by the genre of TMs since the overwhelming majority "of global technical communication is technical instructions" (Sharpe 2014: 15) and still the research in this field seems to be relatively scanty. According to Trimble (1985: 129), TD is "that type of discourse that has as its purpose the transmission of information [...] from writers to readers; therefore it uses only a limited number of rhetorical functions", unlike some other types of specialized discourses, such as academic (cf. Dontcheva-Navratilova 2018) and business (cf. Vogel 2018).

Technical discourse as a typical representative of 'strategic' communication (in contrast to 'expressive' communication) is associated with four criteria, 
namely audience, relationship, purpose and context, "which must be taken into account when categorizing texts as belonging to the technical domain" (Rus 2014: 656). In order to produce effective and useful well-written technical instructions, technical communicators have to consider who they are writing to, since the choice of rhetorical strategies and their linguistic manifestations is highly dependent on the target audiences, which can be both their colleagues and their customers. Thus, the relationship between technical writers and their audiences is of crucial importance. Of the three traditionally identified purposes of communication acts (i.e. persuasion, instruction and entertainment), persuasion and instruction are crucial here: persuasion as the intention of technical writers to persuade the audience of the significance and rightfulness of the guidelines they are receiving, and instruction as the information intended to be transmitted by the technical text in order to enrich the audience's knowledge with regard to some specific technical aspects. Finally, the indisputable role of context, i.e. the professional technical settings, must be mentioned, since all forms of communication arise in a certain social and cultural context (ibid.: 655).

The specific technical facts provided in TMs must be easily accessible for the potential users of particular technical devices. Since the primary goal (but not the only one) is the accurate transmission of technical information, technical communicators try to avoid ambiguity of expression while bearing in mind the expected level of technical proficiency and understanding of the targeted audiences, which can be both professional and lay audiences (cf. "socioliterate competence" in Johns 1997: ix). According to Blake and Bly (1993: 3-19), there are ten important features that make a good technical text: technical accuracy, usefulness, conciseness, completeness, clearness, consistency, correct spelling, punctuation and grammar, targeted audience, good organization and interest. The typical features of well-written instructions are mentioned already in Crystal and Davy (1969: 336), who emphasize the "need to organize the information into a series of clearly defined stages, to avoid ambiguity, and to bear the level of one's audience clearly in mind", which is fully in harmony with what has been emphasized above.

Technical manuals, also labelled user guides, user's guides, user manuals or user's manuals, are written according to specific purposes and audience needs so as to communicate key information to the people who need it (Crowder 2014, Marshall 2018). TMs can take various forms such as user's or owner's, operator's, instruction, service and maintenance, and training manuals. Those under scrutiny represent user's manuals. They usually contain several sections, such as a cover page, a title page, a preface, a contents page, a guide, a troubleshooting section, a FAQ, information about further help, and, in the case of longer TMs, also 
a glossary and an index. However, some of the above-mentioned sections have been excluded from the analysis since they obviously do not comprise directives (e.g. cover page, title page, contents page, glossary, index).

\section{Data and methodology}

\subsection{Data}

The data compiled for this study comprises 30 technical manuals to various technical devices (e.g. TV set, steam iron, electric kettle, bread maker, mobile phone, printer, vacuum cleaner, bottom freezer fridge) and amounts to about 207,000 words. This specialized corpus can be divided into two groups of texts, one comprising 15 manuals written in English as L1 language (texts labelled as ENG-1 - ENG-15) and the other comprising 15 manuals written in Czech as L1 language (texts labelled CZ-1 - CZ-15). The length of the texts varies, the average being 9,230 words in the case of English L1 texts and 4,600 words in the case of Czech L1 texts. With regard to the varying length of the individual texts included in the corpus, all the results discussed in this article have been normalized to the frequency rate of the analysed features per 1,000 words. Moreover, in order to obtain data for the comparative analysis it was necessary to exclude from the studied texts all parts which comprise addresses, figures, graphs, references and tables. The varying length of particular TMs can be explained by two reasons: 1. the manuals to completely different technical devices have been analysed in English and Czech, and 2. even when parallel English and Czech TMs (i.e. the same manuals) were analysed, the English TMs were about 15 to 17 per cent longer than the corresponding Czech ones (cf. Povolná 2018).

\subsection{Methodology}

All thirty TMs were manually excerpted for the first 50 tokens of the structures under examination. In this way the lists of the structures selected for the comparative analysis were prepared. After this, the concordance programme Sketch Engine was used to search for the linguistic realizations of directives. The following step was the manual assessment of the individual tokens found with the help of Sketch Engine, since some of the identified forms can perform other functions than those under scrutiny. Finally, the quantitative results from all the texts were recorded in the form of tables and compared with regard to the research aims stated above. In many cases, there were also other structures identified than those that usually express the directive role (e.g. other modals than those of obligation or necessity). These indirect ways of expressing directives were studied only qualitatively and thus only their most relevant types are exemplified and discussed below. 


\section{Directives as an important means of persuasion}

Directives as major persuasive devices (Swales et al. 1998) and one of the most direct ways of the expression of the persuasive force of the writer over the reader can be regarded as essential interactional metadiscourse markers which writers use to improve the interpersonal relationship with their readers (Halliday 1994, Hyland 2002), in other words they are used to help writers to invoke reader participation, thus clearly adding to the persuasiveness of the text (Jalilifar \& Mehrabi 2014: 30). According to Searle (1976: 11), directives are speech acts that try to "get the hearer to do something", i.e. to persuade the addressee to perform an action. In the literature on speech acts (e.g. Searle 1976, Leech 1983), directives also include requests, invitations and offers. In this study, they are viewed as utterances which "instruct the reader to perform an action or to see things in a way determined by the writer" (Hyland 2002: 215 ) and they normally refer to some future action of the reader. The intention to persuade is the guiding force for the persuaders when choosing concrete linguistic realizations of rhetorical strategies, including directives, to make the readers, i.e. the persuadees, behave in a particular way. Although directives are potentially risky strategies often regarded as bald-on-record threats to face (Brown \& Levinson 1987: 94-101), those applied in TMs obviously concern actions that are to be performed in the readers' own interest, thus requiring no redress from the persuader to minimize the degree of imposition.

Based on Hyland's classification of directives (2002), this investigation views directives as those utterances that typically have three main realization forms: 1. imperatives of full verbs (e.g. follow, hold, press, select), 2. modal verbs of obligation, necessity or prohibition addressed to the reader (e.g. basic safety precautions should be followed, the fridge must be properly installed), and, finally, 3. predicative adjectives expressing the writer's judgement of the necessity or importance to perform an action (e.g. it is also necessary to fill the tank).

Directives can be "classified according to the principal form of activity they direct readers to engage in" (Hyland 2002:217-218), thus enabling the distinctions between textual, physical and cognitive acts. Textual acts guide the reader to refer to either another part of the same text (e.g. Go to the next or previous page.) or another text (e.g. For a list of compatible dongles, go to the official LEGO* MINDSTORMS* website, www.LEGO.com/mindstorms.). Physical acts instruct the reader either to become involved in a research process (e.g. Study the route of a journey you are planning.) or to perform an action in the real world (e.g. Touch and hold a speed dial number.). This type of acts is logically by far the most 
frequent in the TMs analysed. And, finally, cognitive acts impose on the reader some kind of cognitive action, such as to understand something in a certain way (e.g. When selecting envelopes, consider the following components.). The last type is scarcely represented in the data and that is the reason why it is not further subdivided in this study, unlike in Hyland (2002: 218), where cognitive acts are relatively frequent. In agreement with Hyland (ibid.), the third type represents the highest degree of imposition since it is considered more imposing to instruct someone on how to understand a certain standpoint rather than how to perform a concrete action in the real world.

\section{Results}

The following section is divided into three parts. The first one discusses the most important overall results drawn from the analysis of three direct ways in which directives can be expressed. The second offers details concerning the selected realization forms of directives, i.e. both affirmative and negative imperatives, modal verbs and predicative adjectives. And, finally, the third part gives examples and explanations of some possible indirect ways in which directives can also be expressed.

\subsection{Overall results}

My results in Table 1a demonstrate that the highest proportion of directives is expressed by imperatives in all the data, ranging from 73 to 88 per cent of the cases in which directives were identified. Imperatives are unambiguously the most typical linguistic realization of directives both in English L1 (ENG) and Czech L1 (CZ) texts, where they represent 88 and 73 per cent, respectively. These results are almost the same as the results drawn from my previous study (Povolná 2018), in which four groups of parallel texts were compared (both L1 and L2 English as well as Czech TMs). It is evident that English writers of TMs tend to use imperatives of full verbs more frequently than Czech writers; however, when affirmative and negative imperatives are distinguished, as in Table $1 \mathrm{~b}$, the picture of the distribution of imperatives is slightly different, since negative imperatives are much more common in the Czech manuals analysed (by more than 9\%). 


\begin{tabular}{|l|c|c|}
\hline Types of texts & ENG & CZ \\
\hline No. of words in the corpus & 138,436 & 68,996 \\
\hline imperatives & $\mathbf{8 8 . 1 2} \%$ & $73.06 \%$ \\
\hline modals & $7.35 \%$ & $\mathbf{1 2 . 5 5 \%}$ \\
\hline predicative adjectives & $4.51 \%$ & $\mathbf{1 4 . 3 8 \%}$ \\
\hline Total (\%) & $100 \%$ & $100 \%$ \\
\hline
\end{tabular}

Table 1a: Proportions of all directives

\begin{tabular}{|l|c|c|}
\hline Types of texts & ENG & CZ \\
\hline affirmative imperatives & $\mathbf{8 3 . 8 4} \%$ & $59.69 \%$ \\
\hline negative imperatives & $4.28 \%$ & $\mathbf{1 3 . 3 7 \%}$ \\
\hline affirmative modals & $5.61 \%$ & $\mathbf{8 . 5 3} \%$ \\
\hline negative modals & $1.75 \%$ & $\mathbf{4 . 0 2} \%$ \\
\hline affirmative predicative adjectives & $2.95 \%$ & $\mathbf{1 2 . 1 2} \%$ \\
\hline negative predicative adjectives & $1.57 \%$ & $\mathbf{2 . 2 6} \%$ \\
\hline Total (\%) & $100 \%$ & $100 \%$ \\
\hline
\end{tabular}

Table 1b: Distribution of affirmative and negative directives

As demonstrated in Table 1b, with the exception of affirmative imperatives, all the remaining forms of directives studied here, including modal verbs and predicative adjectives, both affirmative and negative, are more frequently represented in the Czech TMs. Since only affirmative imperatives of full verbs are unambiguously more dominant in the English than in the Czech TMs (by more than 24\%), it can now be concluded that imperatives are naturally selected by the overwhelming majority of English technical writers as the most direct and explicit "grammatical method of instructing people" to perform an action (cf. Crystal \& Davy 1969: 237), as shown in:

(1) Select the country where you install the TV. (ENG-1: TV set)

By contrast, Czech technical writers have a slightly stronger tendency (by about $9 \%$ ) to prevent the readers from behaving in an inappropriate, sometimes even 
dangerous, way, as in Example (2). This can be tentatively associated with the expression of slightly greater power and authority claimed by Czech writers when giving technical instructions.

Nepouživejte spotřebič k jiným účelům, než ke kterým je určen.

[Do not use the appliance for other purposes than those for which it is intended.]

(CZ-15: Beverage cooler)

Nevertheless, it must be stated that in general all technical writers, i.e. both English and Czech, frequently apply imperatives not only as the most direct but also as the simplest and clearest way in which the persuasive force can be expressed, thus obviously signalling the dialogic interaction between the technical communicator and the intended audience of TMs. The prominence of the use of imperatives is also emphasized by Sharpe (2014), who speaks about two basic rhetorical features of authentic technical instructions, i.e. "the linear organisational structure, and the reliance on imperative information structures".

As regards the distribution of modal verbs and predicative adjectives in my data, the greatest differences are between the proportions in which affirmative modals and in particular affirmative predicative adjectives are used, since these represent respectively about three and nine per cent more directives in the Czech TMs. By contrast, the proportions of negative predicative adjectives are very similar in all TMs (cf. the difference $0.69 \%$ in Table $1 \mathrm{~b}$ above). These proportions are also reflected in the normalized frequency rates given in Table 2, where negative predicative adjectives $(0.63$ vs 0.72$)$ have very similar frequency counts in all TMs analysed.

\begin{tabular}{|l|c|c|}
\hline Types of texts & ENG & CZ \\
\hline affirmative imperatives & $\mathbf{3 3 . 7 0}$ & 19.04 \\
\hline negative imperatives & 1.72 & $\mathbf{4 . 2 7}$ \\
\hline affirmative modals & 2.26 & 2.72 \\
\hline negative modals & 0.70 & 1.28 \\
\hline affirmative predicative adjectives & 1.19 & $\mathbf{3 . 8 7}$ \\
\hline negative predicative adjectives & 0.63 & 0.72 \\
\hline Average frequency & $\mathbf{4 0 . 1 9}$ & $\mathbf{3 1 . 9 0}$ \\
\hline
\end{tabular}

Table 2: Normalized frequency rates of affirmative and negative directives (per 1,000 words) 
Based on my results, it can now be stated that the much lower proportion (by about 23\%) and much lower relative frequency of occurrence (by almost 15 tokens per 1,000 words) of affirmative imperatives in the Czech manuals can be considered to be compensated by the much more prominent representation (by about 9\%) and slightly higher relative frequency (by about 2.5 tokens) of negative imperatives and affirmative adjectives in these texts (cf. Table $1 \mathrm{~b}$ and Table 2).

As for the raw numbers of the directives under scrutiny, these are not given in any table here. Owing to the differences in the average length between the English and Czech manuals analysed, which is more than twice bigger in the case of English TMs (cf. Subsection 3.1 above), there are logically great differences in the number of cases in which the selected realizations of directives have been identified. That is the reason why, for the purposes of comparison, Table 2 gives only normalized frequency rates of all directives per 1,000 words, while distinguishing affirmative and negative forms.

This table brings further evidence about the distribution of the three linguistic realizations of directives. Affirmative imperatives of full verbs have almost 34 tokens in every 1,000 words in the English sub-corpus. This frequency rate, together with their greatest proportion, which is more than 88 per cent, demonstrates that they are definitely the most typical direct way of the expression of the persuasive force in the English TMs. Apart from Example (1) above, these are also illustrated in the following:

$$
\begin{aligned}
& \text { If a leak is detected, avoid any naked flames or potential sources of ignition and } \\
& \text { air the room in which the appliance is standing for several minutes. }
\end{aligned}
$$

(ENG-3: Bottom freezer fridge)

Imperatives are often applied in association with conditional clauses, as in Example (3). The technical writer mostly instructs the readers that if something happens or does not happen, then they are expected to take action (cf. air the room) or prevent something from happening (cf. avoid any naked flames or potential sources of ignition). The same strategy has been identified in the Czech sub-corpus, as shown in Example (4), where the imperative demontujte dviŕka 'remove the door' follows the conditional clause pokud již chladničku nebudete použivat 'if you do not intend to use the fridge any more':

(4) Pokud již chladničku nebudete použivat, demontujte dviřrka, těsnění, police a uložte je na bezpečné misto.

[If you do not intend to use the fridge any more, remove the door, seal, and shelves and put them in a safe place.]

(CZ-6: Fridge) 
The conditional clauses comprised in Examples (3) and (4) provide background information against which something is viewed as necessary or even urgent, which is a useful strategy often applied in all the TMs analysed. Consequently, it is not surprising that the other realization forms of directives under scrutiny, such as modal verbs and predicative adjectives, also frequently occur in association with conditional clauses.

Moreover, Examples (5) and (6) illustrate that modal verbs expressing obligation and prohibition frequently occur not only in association with constructions that are conditions, as in Example (5), but also in constructions that function as conditions. This is shown in Example (6), where the conveyed meaning of the whole sentence is 'If a nonspace entry is not made in the first character location, the X-GAUGE will not be an active gauge', although the if-clause is not used. The technical writer informs the readers under what conditions something important may or may not happen, or rather under what circumstances something urgent must be performed.

If you forget your description password, you cannot restore encrypted data and personal information.

(ENG-9: Movie camera)

A nonspace entry must be made in the first character location, or the X-GAUGE will not be an active gauge.

(ENG-15: Electronic car tester)

As shown in the above tables, the less prominent representation and much lower normalized frequency of affirmative imperatives in the Czech manuals is to a certain extent compensated for by the relatively higher normalized frequency rates of negative imperatives and affirmative predicative adjectives, which both have the relative frequency of occurrence of about 2.5 tokens per 1,000 higher than those found in the English TMs. Negative imperatives are illustrated in Example (2) above and affirmative adjectives in the example that follows:

(7) Všechny obaly je nutné před použitím myčky odstranit.

[It is necessary to remove all packagings before using the dishwasher.]

(CZ-8: Dishwasher)

Czech technical writers often resort to the use of predicative adjectives in order to express directives when a suitable adjective, such as nutné 'necessary' in Example (7), is at their disposal. However, it must be noted here that Czech predicative adjectives, also called modal predicatives by Šipková (2017), are often translated into English by different linguistic means, although the corresponding 
English equivalents exist. This tendency was demonstrated in my previous study (cf. Povolná 2018), in which parallel English and Czech texts were analysed. The analysis thus enabled the comparison of the sentences conveying exactly the same meaning, but still using different realization forms. Moreover, it was also demonstrated that the two compared languages sometimes give preference to different ways of expressing directives even if equivalent realization forms exist. This can also be considered one of the reasons why the English technical writers included in my investigations (both current and 2018) resort to the use of imperatives much more than the Czech ones.

While the results presented above show general tendencies in the expression of directives in my data, the following part offers further details on the three linguistic realizations of directives selected for the analysis.

\subsection{Selected realization forms of directives}

This subsection starts with the verbs most typically used in the imperative forms when expressing directives, then it exemplifies the use of modal verbs of obligation, prohibition and necessity, and, finally, it gives some details about the application of predicative adjectives identified in my data when they have directive force.

\begin{tabular}{|l|c|c|}
\hline Types of texts & ENG & CZ \\
\hline No. of words & 138,436 & 68,996 \\
\hline Textual acts & $3.58 \%$ & $5.33 \%$ \\
\hline Physical acts & $\mathbf{9 5 . 8 9 \%}$ & $\mathbf{9 4 . 4 6 \%}$ \\
\hline Cognitive acts & $0.53 \%$ & $0.21 \%$ \\
\hline Total (\%) & $100 \%$ & $100 \%$ \\
\hline
\end{tabular}

Table 3: Distribution of imperative verbs (\%) according to Hyland (2002)

The verbs used in the imperative forms are grouped according to Hyland's classification (2002) into three major categories, namely those performing textual, physical and cognitive acts (cf. Section 4 above). With regard to the type of the texts under scrutiny and consequently the types of activities which the readers are mostly instructed to perform, it is not surprising that the overwhelming majority of the verbs included in Table 3 belong to the verbs referring to some physical acts, representing about 95 per cent of all imperatives in both English and Czech TMs. The highest frequency rates were recorded for the verbs tap (klepněte), 
use (použijte or použivejte), select (zvolte or vyberte), press (stiskněte or stlačte) and hold (držte) (some of the English verbs have two equivalents in Czech), all referring to some concrete real-world actions and all obviously associated with the actions to be performed according to the technical instructions given in the TMs analysed. Since all provide guidance for various technical devices (e.g. mobile phone, TV set, camera, electric kettle, steam iron, bread maker, vacuum cleaner), they mostly require the performance of concrete actions in the real world or, much less frequently, research process, as are the cases of the imperatives remove, replace and read in Examples (8) and (9).

\section{Remove the filter from the cover and replace it with a new filter.}

(ENG-3: Bottom freezer fridge)

(9) Please carefully read this user guide before using the device for the first time to ensure safe and proper use.

(ENG-9: Movie camera)

Only occasionally are the readers of TMs directed to refer to another text, thus performing textual acts according to Hyland (2002). These verbs represent approximately four to five per cent of the verbs included in Table 3 . They instruct the readers to refer to another part of the same text, i.e. the very same manual they are just reading, as in Example (10), or to refer to a completely different text, usually one which is available on-line, as in Example (11). The most typical verbs performing textual acts in my corpus are see (podivejte se), refer (obratte se) and go to (jdète na), all enabling reference both to the same text and to another text, which is the reason why they are not further subdivided in my results.

See the Using Your Fridge section for more information.

(ENG-3: Bottom freezer fridge)

(11) For more information, go to tomtom.com/mapshare.

(ENG-7: GPS)

As for cognitive acts (cf. Hyland 2002), the readers of TMs are instructed to perform them even less frequently than textual acts. They represent only $0.2-0.5$ per cent of all imperatives identified in the analysis. They are exemplified by the imperative form of the English verb consider in Example (12) and that of the Czech verb považujte 'consider' in Example (13). The English verbs consider and remember and their Czech equivalents považujte and pamatujte (si) are in fact the only ones in my data that refer to cognitive acts. 
(12) Also consider the capabilities of your computer or TV to be sure your hardware can support the selected resolution.

(ENG-14: Camera)

(13) Instrukce v návodu považujte za součást spotřebiče a postupte je jakémukoliv dalšimu uživateli spotřebiče.

[Consider the instructions in the manual as part of the appliance and pass them on to any other user of the appliance.]

(CZ-3: Electric vacuum cleaner)

Summing up, it must be stated that my results concerning imperatives and their classification into three groups of acts only show minor cross-cultural differences between the English and Czech manuals analysed. Verbs referring to physical and cognitive acts tend to be slightly more frequent in the English sub-corpus while those related to textual acts are more common in the Czech one. My results are different from Hyland's findings (2002), since Hyland analysed academic discourse, namely research articles, textbooks and student reports, in which directing the readers to perform textual or cognitive acts is apparently more common than the guidance to perform real-world actions, which is obviously typical of my data.

The results concerning the most important modal verbs expressing obligation, necessity or prohibition are given in Tables $4 \mathrm{a}$ (English manuals) and $4 \mathrm{~b}$ (Czech manuals). They are broken down according to whether the particular modal is affirmative or negative, thus lucidly illustrating the distinction, for instance, between the necessity to perform an action and prohibition from taking it. Since some of the modals can perform other functions than those under scrutiny (cf. e.g. Palmer 2001: 14), it is necessary to note here that only those tokens of modal verbs that primarily express obligation, necessity or prohibition are included in the following tables and those of them with normalized frequency rates higher than 0.5 are highlighted in bold. 
Cross-cultural Variation in the Expression of Persuasive Power in the Genre of Technical Manuals: The Case of Directives

\begin{tabular}{|l|l|c|c|}
\hline affirmative modals & negative modals & affirmative & negative \\
\hline must & must not & $\mathbf{1 . 0 6}$ & 0.06 \\
\hline have to/has to & do/does not have to & 0.11 & 0.02 \\
\hline need to/needs to & do/does not need to & 0.37 & 0.05 \\
\hline & may not & & 0.04 \\
\hline should & should not & $\mathbf{0 . 7 2}$ & 0.09 \\
\hline & shall not & & 0.05 \\
\hline & cannot & $\mathbf{2 . 2 6}$ & $\mathbf{0 . 7 0}$ \\
\hline Average normalized frequency & & $\mathbf{2 . 9 6}$ & \\
\hline
\end{tabular}

Table 4a: Modal verbs in English manuals (normalized frequencies)

The most typical modal verb expressing obligation and necessity is must with its relative frequency rate of 1.06 tokens in every 1,000 words, although some authors state that its usage has undergone a dramatic decline (e.g. Leech 2003, Smith 2003, Hinkel 2009). According to Leech and Svartvik (1994: 163) and Quirk et al. (1985: 225), this modal, which is included in Example (14), carries a greater degree of the writer's authority than need/needs to $(0.37)$ and have/ has to (0.11), which are both much less frequent in my data. The semi-auxiliary have/has to (Quirk et al. 1985: 145) is included among modal verbs in this study when it appears in modal constructions expressing obligation and necessity. Smith (2003) reports that the lowering frequency rates of must and have/has to tend to be partly compensated for by the growing use of need/needs to. This is only partly evidenced by my results, though. The marginal modal need/needs to (Quirk et al. 1985: 138ff), which is shown in Example (15), seems to have a slightly rising frequency $(0.37)$ in comparison with the very low frequency rate of have/has to (0.11) in my corpus.

(14) You must enter the password each time you turn on the device.

(ENG-13: Mobile phone)

If the country is correct, continue with step 2. If the country is not correct, you need to start a reinstallation.

(ENG-1: TV set)

As illustrated in Example (15), the presence of modal verbs (e.g. need to) is often associated with the use of conditional clauses, which, similarly to the cases 
in which imperatives are used (e.g. continue), describe some kind of condition or situation that enhances the necessity to take an action.

Based on the frequency rates given in Table $4 \mathrm{a}$, it can now be stated that when expressing obligation and necessity (i.e. the two modal meanings not treated separately here in agreement with e.g. Perkins 1983, Smith 2003 and Leech 2005), most English technical writers tend to give preference to the verb must, which carries the strongest degree of directive force (Biber et al. 1999: 495) and thus clearly instructs the readers on what it is necessary to do. The same applies to its Czech equivalent, i.e. musi/museji/musite, which is much more dominant in my data since its frequency rate (2.51) is double the frequency rate of the verb must (1.06), as indicated in Tables $4 \mathrm{a}$ and $4 \mathrm{~b}$. The Czech verb is included in the following example:

(16) Nové barevné prádlo musíte při prvním praní prát samostatně.

[You must wash new colourful underwear separately when washing it for the first time.]

(CZ-14: Washing machine)

\begin{tabular}{|l|l|c|c|}
\hline affirmative modals & negative modals & affirmative & negative \\
\hline musí/musejímusíte & nemusí & $\mathbf{2 . 5 1}$ & 0.16 \\
\hline & nesmí/nesmějí & & $\mathbf{1 . 1 2}$ \\
\hline měl by/měli by/měli byste & & 0.21 & \\
\hline Average normalized frequency & $\mathbf{4 . 0 0}$ & $\mathbf{2 . 7 2}$ & $\mathbf{1 . 2 8}$ \\
\hline
\end{tabular}

Table 4b: Modal verbs in Czech manuals (normalized frequencies)

Of the remaining modal verbs expressing obligation and necessity, the most prominent one is the verb should, which, while expressing a lower degree of directive force than must, have/has to, and need/needs to, amounts to a normalized frequency as high as 0.72 tokens per 1,000 words in the English TMs. This result is in agreement with Leech (2003: 237), who reports that must when expressing obligation shows a strongly declining usage (although not so distinct in my material), while the frequency rates of should have been steadily rising. The use of should, which "provides a hedged expression of obligation [...] and is typically regarded as more polite" (Biber et al. 1999: 495), is often associated with what can be understood as recommendations or giving a piece of advice (cf. Perkins 1983), as illustrated in Examples (17) and (18) below. According to Leech (2005) and Hinkel (2009), the modal should, similarly to the other obligation/necessity 
modals discussed above, refers to logical necessity based on logical deduction, which instructs the readers to act "perhaps through a sense of duty, through self-discipline, or merely through the sense of expediency" (Leech 2005: 94). This modal is more commonly used (0.72) by English technical writers than its Czech equivalent měl by/měli by/měli byste $(0.21)$ by Czech writers (cf. Tables $4 \mathrm{a}$ and $4 \mathrm{~b}$ ). Consequently, it can now be assumed that English writers sometimes tend to be slightly less direct than the Czechs when providing guidance to the readers on what to perform, and therefore they prefer giving instructions in the form of what looks more like recommendations. This is also in agreement with Leech (2003: 237), who holds the view that the decline in the use of must and a shift to need to and should is possibly "associated with a tendency to suppress or avoid overt claims to power and authority by the speaker or writer", which is evidenced by the following examples. In the latter example, the avoidance of direct claims is also achieved by the use of the passive (i.e. it should be read) rather than active voice (i.e. you should read).

(17) In the interest of safety and to reduce distractions while you are driving, you should always plan a route before you start driving.

(ENG-7: GPS)

(18) This symbol alerts the user that important literature concerning the operation and maintenance of this unit has been included. Therefore, it should be read carefully in order to avoid any problems.

(ENG-10: Monitor)

The most typical modal used to express prohibition in the Czech TMs is the verb nesmínesmějí. While its English counterparts must not (0.06) and may not (0.04) are rather scarce, the Czech verb amounts to more than one token per 1,000 words (1.12), thus representing the most common Czech modal used to express prohibition. This verb, which is included in Example (19), illustrates the fact that the Czech technical writers have a stronger tendency to prevent readers from taking inappropriate, sometimes even dangerous, action, thus using negative modals much more in my data than the English writers (cf. the use of negative imperatives discussed in Subsection 5.1 above).

(19) Žehlička nesmí být ponechána bez dozoru, je-li připojena $k$ síti. [The iron must not be left without supervision if plugged in power supply.]

(CZ-4: Steam iron) 
When expressing prohibition the modals must not and may not are much less common than their slightly weaker equivalent cannot (0.39). Some of these modals are included in the following examples:

You cannot use all functions, except for emergency calls, until you unlock the device.

(ENG-9: Movie camera)

You may not copy the Software onto any public network.

(ENG-5: Monitor)

According to Leech and Svartvik (2003: 165), "a weakened prohibition (more like negative advice) can be expressed by shouldn't, oughtn't to $<\operatorname{esp} \mathrm{BrE}>$, and had better not", which are all almost non-existent in my corpus (cf. Table 4a above), in which should not amounts to a frequency rate of only 0.09 , and ought not to, similarly to its affirmative counterpart ought to, does not occur at all. The above tendency is also commented on in Leech (2003: 234-235), who claims that some individual modals, such as ought to, are declining.

You should not carry the device in a breast pocket.

(ENG-7: GPS)

Unlike the English prohibition modal should not, which is included in Example (22), its Czech equivalent nemél by/neméli by/neméli byste has not been identified in my data at all. This is probably caused by the Czech technical writers' preference for using the much stronger modal nesmínesměji (1.12) to prevent the readers from taking dangerous action, as in Example (19). As already discussed, this Czech modal has several English equivalents which express different degrees of directive force and which are used with different frequency rates, the most common one being the modal cannot (0.39), shown in Example (20).

Finally, it remains to discuss and exemplify the use of predicative adjectives in my data. Tables 5a and 5b present my results from the English and Czech manuals, respectively. Since the majority of the predicative adjectives identified in the analysis have very low frequency rates, even those with more than 0.1 tokens per 1,000 words are included in the tables. Unlike my results concerning modals (cf. Tables $4 \mathrm{a}$ and $4 \mathrm{~b}$ above), there are no results highlighted in bold in Table 5a since no predicative adjectives with frequencies higher than 0.5 have been found in the English TMs. However, since the average frequency of predicative adjectives is not so low in comparison with that of modals (cf. Table 2 
in Subsection 5.1 above), it can now be confidently stated that my results indicate that there is a wide choice of relatively infrequent predicative adjectives that can express technical writers' judgements of the necessity to perform an action or prohibition from taking it.

\begin{tabular}{|l|l|c|c|}
\hline affirmative adjectives & negative adjectives & affirmative & negative \\
\hline available & not available & 0.13 & 0.43 \\
\hline designed & not designed & 0.18 & 0.01 \\
\hline necessary & not necessary & 0.10 & 0.02 \\
\hline required & not required & 0.15 & 0.02 \\
\hline subject to & & 0.21 & \\
\hline Average normalized frequency & $\mathbf{1 . 8 1}$ & $\mathbf{1 . 1 8}$ & $\mathbf{0 . 6 3}$ \\
\hline
\end{tabular}

Table 5a: Predicative adjectives in English manuals (normalized frequencies)

The results given in Table 5a show that the variety of the predicative adjectives commonly used in the English TMs under scrutiny is not great in spite of their wide repertoire. On account of their frequency rates, only five predicative adjectives are listed in the table although there are many others (such as advised, applicable, dangerous, important, intended, recommended and vital) that the English technical writers have at their disposal. Two of the more frequent adjectives, namely not available (0.43) and designed (0.18), and one of those that is rather scarce, notably vital (0.02), are shown in the following examples:

(23) The zoom feature is not available when using the front camera in selfie mode.

(ENG-9: Movie camera)

(24) The supplied items are designed only for this device and may not be compatible with other devices.

(ENG-13: Mobile phone)

(25) Since all methods of conventional electricity generation have a negative effect on the environment (acidic and climate-influencing emissions, radioactive waste, etc.), it is vital to conserve energy.

(ENG-4: Monitor)

The adjective vital in the above example illustrates a typical construction identified in both compared languages, i.e. the use of a predicative adjective followed by an infinitive construction, which is to-infinitive in English. 


\begin{tabular}{|c|c|c|c|}
\hline affirmative adjectives & negative adjectives & affirmative & negative \\
\hline $\begin{array}{l}\text { je dostupný } \\
\text { 'it is accessible' }\end{array}$ & & 0.30 & \\
\hline $\begin{array}{l}\text { je důležité } \\
\text { 'it is important' }\end{array}$ & & 0.12 & \\
\hline $\begin{array}{l}\text { je možné } \\
\text { 'it is possible' }\end{array}$ & $\begin{array}{l}\text { není možné } \\
\text { 'it is not possible' }\end{array}$ & 0.70 & 0.12 \\
\hline $\begin{array}{l}\text { je možno } \\
\text { 'it is possible' }\end{array}$ & $\begin{array}{l}\text { není možno } \\
\text { 'it is not possible' }\end{array}$ & 0.19 & 0.01 \\
\hline $\begin{array}{l}\text { je nutné } \\
\text { 'it is necessary' }\end{array}$ & $\begin{array}{l}\text { není nutné } \\
\text { 'it is not necessary' }\end{array}$ & 0.57 & 0.04 \\
\hline \multirow[t]{2}{*}{$\begin{array}{l}\text { je nutno } \\
\text { 'it is necessary' }\end{array}$} & $\begin{array}{l}\text { není nutno } \\
\text { 'it is not necessary' }\end{array}$ & 0.14 & 0.01 \\
\hline & $\begin{array}{l}\text { není odpovědný } \\
\text { 'it is not responsible' }\end{array}$ & & 0.12 \\
\hline $\begin{array}{l}\mathrm{je} / \mathrm{bude} \text { třeba } \\
\text { 'it is/will be necessary' }\end{array}$ & $\begin{array}{l}\text { není třeba } \\
\text { 'it is not necessary' }\end{array}$ & 0.52 & 0.01 \\
\hline $\begin{array}{l}\text { je určen } \\
\text { 'it is intended' }\end{array}$ & $\begin{array}{l}\text { není určen } \\
\text { 'it is not intended' }\end{array}$ & 0.65 & 0.20 \\
\hline $\begin{array}{l}\text { je vhodný } \\
\text { 'it is suitable' }\end{array}$ & $\begin{array}{l}\text { není vhodný } \\
\text { 'it is not suitable' }\end{array}$ & 0.37 & 0.12 \\
\hline Average normalized frequency & 4.59 & 3.87 & 0.72 \\
\hline
\end{tabular}

Table 5b: Predicative adjectives in Czech manuals (normalized frequencies)

Note: It must be noted here that it was necessary in Table $5 \mathrm{~b}$ to list Czech predicative adjectives carrying negative meaning together with the verb to be 'být', since the expression of negation cannot be separated from the verb in this case. For example, not responsible is listed as neni odpovédny' 'it is not responsible'. This table also offers the English equivalents of the Czech predicative adjectives.

As demonstrated in Tables 5a and 5b, the application of predicative adjectives having persuasive force is much more common in the Czech sub-corpus. This is particularly noteworthy when affirmative predicative adjectives are taken into consideration, since they amount to almost four tokens (3.87) in the Czech TMs in contrast to only one token (1.19) per 1,000 words in the English TMs. As already mentioned, Czech technical writers often use affirmative predicative adjectives to express directives in order to compensate for the less prominent 
use of affirmative imperatives. The following examples comprise the adjective je nutné 'it is necessary' (0.57), which together with its less common and bookish version je nutno 'it is necessary' (0.14), represents the most typical predicative adjective identified in the Czech sub-corpus:

(26) Pro bezporuchový chod vysavače je nutné použivat testované filtry a mikrofiltry doporučené výrobcem.

[For trouble-free operation of the vacuum cleaner it is necessary to use filters and microfilters tested by the producer.]

(CZ-2: Vacuum cleaner)

Při vy̌šsich teplotách je nutno dveře otevrít nebo sejmout.

[With higher temperatures, it is necessary to open or replace the door.]

(CZ-9: Combined stove)

As given in Internetová jazyková př́ručka and Mluvnice češtiny (2), Tvaroslovi (1986: 75-76), the bookish variant nutno of the adjective nutné is applied particularly in predicative position with evaluation and modal meanings, which is clearly the case of Example (27).

Of the other predicative adjectives identified in my corpus, the Czech je možné 'it is possible' (0.70) (together with its bookish version je možno 'it is possible'), je/bude třeba 'it is/will be necessary' $(0.52)$ and je určen 'it is intended' $(0.65)$ are worthy of attention, owing to their frequency rates higher than 0.5 tokens per 1,000 words. Two of these adjectives are included in the examples that follow.

(28) Je třeba dbát na doporučenou váhu prádla podle tabulky programů.

[It is necessary to pay attention to the recommended weight of laundry according to the program table.]

(CZ-14: Washing machine)

(29) Výrobekje určen pouze pro použiti v domácnostech a podobné účely (vobchodech, kancelárích a podobných pracovištich, $v$ hotelich, motelech a jiných obytných prostředich, $v$ podnicich zajištujicich nocleh se snídani)! Není určen pro komerčni použití!

[The product is intended for home use and similar (in shops, offices and similar workplaces, in hotels, motels and other residential environments, in facilities providing accommodation with breakfast). It is not intended for commercial use!]

(CZ-2: Vacuum cleaner)

While Example (28) includes the predicative adjective followed by the infinitive construction, namely je třeba dbát 'it is necessary to pay attention', Example (29) comprises both the affirmative adjective je určen 'it is intended' 
and its negative counterpart neni určen 'it is not intended' when followed by a prepositional phrase, namely pro použiti' 'for use'.

Summing up, it can be stated that all the above examples clearly illustrate how both English and Czech technical writers use predicative adjectives followed frequently by infinitive or prepositional constructions in order to express directive force.

Although it was not possible to exemplify here all typical instances of the realization forms of directives under scrutiny, all tokens of imperatives, modal verbs and predicative adjectives shown here have provided evidence that not only the whole text of the given TM (i.e. linguistic (verbal) context), including many visual means, but also the whole situational context (i.e. context of situation) in which TMs are read and followed obviously contribute to the effectiveness and persuasiveness of the technical instructions and help the readers perform the required actions, since, as mentioned in Tárnyiková (2007: 64), "the interpretative contextual clues are retrievable from the overall communicative situation". It remains to note here that some other possible ways in which directives can be expressed are suggested in the following subsection.

\subsection{Some notes on the possible linguistic means used to express directives indirectly}

This subsection attempts to suggest some possible indirect ways in which directives can be expressed, i.e. when using other linguistic means than those that primarily perform the directive role and which are discussed above. Accordingly, the use of other modals than those expressing obligation, necessity and prohibition is illustrated and briefly discussed, then the application of conditional clauses, and, finally, the use of rhetorical questions is briefly mentioned, since these are the linguistic means most frequently identified in my data during the manual assessment of the realizations of directives under scrutiny.

The most important modal verbs that can also contribute to the expression of directive force are those associated with possibility. The English could and its Czech equivalent mohlo by/mohli by, which were found only in the affirmative forms in my corpus, primarily express possibility of what might happen, which is the reason why they are not listed in any table above. However, as illustrated in Examples (30) and (31), they can also contribute to the expression of persuasiveness.

Replacing the water filter could cause a small amount of water to drain. Place a cup under the filter head to catch any water.

(ENG-3: Bottom freezer fridge) 
(31) Nenaplňujte konvici studenou vodou za účelem rychlého ochlazení. Mohlo by to snižit životnost topného tělesa.

[Do not fill the kettle with cold water in order to cool it down quickly. It could reduce the life of the heating element.]

(CZ-5: Electric kettle)

Example (30) comprises the modal could, which, thanks to the context, carries the meaning of the imperative 'do not replace the water filter since otherwise you may cause a small amount of water to drain'. This directive role of the modal is further enhanced by the immediately following piece of advice stating what the reader should do if the instruction is not followed. Similarly, the sentence with the modal mohlo by in Example (31) is preceded by a sentence with the imperative nenaplnujte 'do not fill'. The first sentence represents the linguistic context against which the subsequent sentence must be interpreted, thus causing the modal verb mohlo by to function as a directive, which conveys the meaning 'do not reduce life of the heating element by filling the kettle with cold water'.

It must be noted here that other modals primarily used to express possibility, such as can, may and might, can also contribute to the persuasiveness of technical texts. However, since their detailed study is out of the scope of the present paper, it suffices to illustrate here one more, namely can and its Czech equivalent müže/ můžete. It is worth mentioning that these modals are often used together with conditional clauses, as the following examples illustrate:

(32) If the key you need is not on the TV remote control, you can select the key in the Options menu.

(ENG-1: TV set)

The use of can in the above example can be understood, in agreement with Leech (1987: 73), as a suggestion for future action, namely 'select the key in the Options menu'. Consequently, this modal represents what Leech labels as "a democratic imperative" and what thus clearly contributes to the persuasiveness of the text. Similar cases of indirect ways in which directives can be expressed are quite common in both compared languages in my data. This is demonstrated in Example (33), in which the modal můžete 'you can' carries, similarly to can in Example (32), the imperative meaning, i.e. 'sklopte ji' ('fold it').

Pokud poličku nepoužíváte, můžete ji sklopit nebo dokonce vyjmout. [If you do not use the shelf, you can fold it or even remove it.]

(CZ-7: Dishwasher) 
Some of the modal verbs illustrated above are included in the constructions which comprise conditional clauses, since conditional clauses often operate together with modal verbs (but not only), while both contributing to the expression of directive force (for more examples of conditional clauses, cf. Subsection 5.2 above).

As regards rhetorical questions, which, in my opinion, can also contribute to the effectiveness and persuasiveness of technical texts, there are only a few concrete realization forms identified in my corpus. One of them follows:

Did you overload your dryer? Divide your larger load into a number of smaller loads.

(ENG-12 Electric and gas dryer)

The rhetorical question actually carries the meaning 'Do not overload your dryer', thus obviously performing the directive function. By using rhetorical questions, the writer enhances the dialogic nature of technical discourse, i.e. the dialogue between the technical communicator and their targeted readers. However, rhetorical questions are rather scarce in the English sub-corpus and almost non-existent in the Czech sub-corpus. One of the rare examples follows:

Co lze dělat, když chléb chutná po droždí? a) Tato chut' je často odstraňována přidáním cukru. b) ...

[What can you do if bread tastes like yeast? a) This taste can often be removed by adding sugar. b) ...]

(CZ-1 Bread maker)

The above rhetorical question is applied as a useful means of attracting the readers' attention and then introducing one or more suggestions on what to do in order to perform the task stated in the given question successfully.

All the examples presented above clearly demonstrate how complex the identification and interpretation of directives can be, since "both the form of the language (as in the case of rhetorical questions) and its content (as when the speaker is appealing to some authoritative figure or the logical reasoning skills of the audience) contribute to the overall persuasive effect" (Halmari 2005: 116), thus enhancing the effectiveness and persuasiveness of the text.

Finally, it must be emphasized that this subsection presents only a few suggestions on some indirect ways in which directives can also be expressed. Only further research into other linguistic realizations can explicate all possibilities that are at the technical writers' disposal when giving instructions to their readers. 


\section{Conclusion}

Since the overwhelming majority of the results drawn from my crosscultural analysis of directives in the genre of technical manuals have already been mentioned in the concluding parts of the Results section, let me just briefly summarize them here with regard to the research aims of this paper.

Based on my analysis, it can be concluded that imperatives are unambiguously the most important direct way of the expression of persuasive force. They represent the simplest and most straightforward way of instructing the readers of TMs on what to do. My data, however, show some cross-cultural differences, especially when affirmative and negative imperatives are compared. While the English technical writers give preference to instructing their readers to take action, the Czech writers have a tendency to prevent them from taking it. This cross-cultural difference is reflected in the much more prominent application of affirmative imperatives in the English sub-corpus and, on the other hand, the frequent application of negative imperatives in the Czech part, which can be associated with the expression of greater power and authority by Czech technical writers, who also tend to use slightly stronger modal verbs. It can also be stated that the lower proportion and much lower frequency rate of affirmative imperatives in the Czech TMs seems to be compensated for by the more prominent use of negative imperatives and affirmative predicative adjectives.

All three possible direct ways in which directives can be expressed are applied in both compared languages, although there are some cross-cultural differences. These can be caused above all by some language-specific conventions which technical writers try to follow in order to meet their readers' expectations. This is important especially with regard to the fact that meeting the readers' expectations usually entails producing effective and useful well-written technical texts which can persuade the readers to perform the actions required in the instructions. As already mentioned, TMs must be clearly and comprehensibly formulated with 'maximal relevance' of the conveyed message (cf. Sperber \& Wilson 1986, Crowder 2014, Marshall 2018) so that the readers can realize that to follow the instructions is in their own interest. That is the reason why the most straightforward and direct ways of expressing directives (i.e. imperatives) are most typically applied in both compared languages.

Finally, it must be acknowledged that on account of the limited size and composition of my corpus and the scope of the present paper, only further research into other technical texts can prove whether the conclusions suggested here can be of general application, for example, when providing guidance to technical writers on how to produce texts that are structurally accurate, functionally effective and communicatively appropriate for their targeted audiences (cf. Pérez-Llantada 2002). 


\section{Acknowledgement}

This article is an output of the grant project 17-16195S Persuasion across Czech and English Specialised Discourses, which is supported by the Czech Science Foundation.

\section{References}

Adam, M. (2017) 'Persuasion in religious discourse: Enhancing credibility in sermon titles and openings.' Discourse and Interaction 10(2), 5-25.

Biber, D., Johansson, S., Leech, G., Conrad, S. and Finegan, E. (1999) Longman Grammar of Spoken and Written English. Harlow: Pearson.

Blake, G. and Bly, R. W. (1993) The Elements of Technical Writing. New York: McMillan.

Brown, P. and Levinson, S. (1987) Politeness: Some Universals in Language Usage. Cambridge: Cambridge University Press.

Crowder, A. (2014) Technical Writing - Technical Communication: Technical Writing Instruction and Real World Professional Guidance. Kindle Edition. KRB Instructional Publications. Amazon Digital Services LLC.

Crystal, D. and Davy, D. (1969) Investigating English Style. London: Longman.

Dontcheva-Navratilova, O. (2011) Coherence in Political Speeches. Brno: Masaryk University.

Dontcheva-Navratilova, O. (2018) 'Persuasion in academic discourse: Cross-cultural variation in Anglophone and Czech academic book reviews.' In: Pelclová, J. and Weilun, L. (eds) Persuasion in Public Discourse. Cognitive and Functional Perspectives. Amsterdam and Philadelphia: John Benjamins. 227-257.

Halliday, M. A. K. (1994) An Introduction to Functional Grammar. $2^{\text {nd }}$ ed. London: Edward Arnold.

Halmari, H. (2005) 'In search of "successful" political persuasion. A comparison of the styles of Bill Clinton and Ronald Reagan.' In: Halmari, H. and Virtanen, T. (eds) Persuasion across Genres. Amsterdam and Philadelphia: John Benjamins. 105-134.

Halmari, H. and Virtanen, T. (eds) (2005) Persuasion across Genres. Amsterdam and Philadelphia: John Benjamins.

Hinkel, E. (2009) 'The effects of essay topics on modal verb uses in L1 and L2 academic writing.' Journal of Pragmatics 41, 667-683.

Hyland, K. (2002) 'Directives: Arguments and engagement in academic writing.' Applied Linguistics 23(2), 215-239.

Internetová jazyková přiručka: Konkurence jmenných a složených tvarů přídavných jmen, konkurence přídavných jmen a příčestí trpného. Online document. 2 June 2019 http://prirucka.ujc.cas.cz/?id=420.

Jalilifar, A. and Mehrabi, K. (2014) 'A cross-disciplinary and cross-cultural study of directives in discussion and conclusions of research articles.' Iranian Journal of Language Teaching Research 2(1), 27-44.

Johns, A. (1997) Text, Role, and Context. Developing Academic Literacies. Cambridge: Cambridge University Press.

Lakoff, R. T. (2000) The Language War. Berkeley, Los Angeles and London: University of California Press.

Leech, G. (1983) Principles of Pragmatics. New York: Longman.

Leech, G. (2003) 'Modality on the move: The English modal auxiliaries.' In: Pacchinetti, R., Krug, M. and Palmer, F. (eds) Modality in Contemporary English. Berlin and New York: Mouton de Gruyter. 223-240. 
Leech, G. (2005) Meaning and the English Verb. $3^{\text {rd }}$ ed. Harlow: Longman.

Leech, G. and Svartvik, J. (2003) A Communicative Grammar of English. $3^{\text {rd }}$ ed. Harlow: Pearson.

Marshall, C. (2018) Technical Writing for Business People (Business and Technical Writing). Swindon: BCS, The Chartered Institute for IT.

Miller, G. R. (ed.) (1980) Persuasion: New Directions in Theory and Research. Beverly Hills, CA: Sage. 11-28.

Mluvnice češtiny (2), Tvarosloví (1986) Praha: Academia.

Palmer, F. R. (2001) Mood and Modality. Cambridge Textbooks in Linguistics. $2^{\text {nd }}$ ed. New York: Cambridge University Press.

Pérez-Llantada, C. (2002) 'Designing new genre identities in scientific and technical discourse: Cognitive, social and pedagogical implications.' Journal of English Studies 3, 251-263.

Perkins, M. (1983) Modal Expressions in English. London: Frances Pinter.

Perloff, R. (2010) The Dynamics of Persuasion. Communication and Attitudes in the $21^{\text {st }}$ Century. New York and London: Routledge.

Povolná, R. (2018) 'On some persuasive strategies in technical discourse: Cross-cultural analysis of directives in English and Czech technical manuals.' Topics in Linguistics $19(2), 72-85$.

Quirk, R., Greenbaum, S., Leech, G. and Svartvik, J. (1985) A Comprehensive Grammar of the English Language. New York: Longman.

Rus, D. (2014) 'Technical communication as strategic communication. Characteristics of the English technical discourse.' Procedia Technology 12, 654-658.

Searle, J. R. (1976) 'A classification of illocutionary acts.' Language in Society 5, 1-23.

Sharpe, M. (2014) 'Language forms and rhetorical function in technical instructions.' English for Specific Purposes World 43(15). Online document. 6 June 2019 http://www.esp-world.info.

Smith, N. (2003) 'Changes in the modals and semi-modals of strong obligation and epistemic necessity in recent British English.' In: Pacchinetti, R., Krug, M. and Palmer, F. (eds) Modality in Contemporary English. Berlin and New York: Mouton de Gruyter. 241-267.

Sperber, D. and Wilson, D. (1986) Relevance. Communication and Cognition. Oxford: Blackwell.

Swales, J. M., Ahmad, U. K., Chang, Y., Chavez, D., Dressen, D. F. and Seymor, R. (1998) 'Consider this: The role of imperatives in scholarly writing.' Applied Linguistics 19(1), 97-121.

Šipková, M. (2017) 'O modálních predikativech slovesného původu typu To přende, (se) patři...zbórat.' Naše řeč 100(4), 265-271.

Tárnyiková, J. (2007) Sentence Complexes in Text. Processing Strategies in English and in Czech. Olomouc: Univerzita Palackého.

Trimble, L. (1985) English for Science and Technology: A Discourse Approach. Cambridge: Cambridge University Press.

Virtanen, T. and Halmari, H. (2005) 'Persuasion across genres. Emerging perspectives.' In: Halmari, H. and Virtanen, T. (eds) Persuasion across Genres. Amsterdam and Philadelphia: John Benjamins. 3-24.

Vogel, R. (2018) 'Persuasion in business documents: Strategies for reporting positively on negative phenomena.' Ostrava Journal of English Philology 10(1), 55-70. 
Renata Povolná is Associate Professor of English Linguistics at Masaryk University, Brno, Czech Republic. Her research interests lie in the area of discourse analysis, pragmatics and conversation analysis, concentrating mainly on academic and technical discourse. She has published the books Spatial and Temporal Adverbials in English Authentic Face-to-Face Conversation (2003) and Interactive Discourse Markers in Spoken English (2010) and co-authored Cohesion and Coherence in English Discourse (2012). She is co-editor of Coherence and Cohesion in Spoken and Written Discourse (2009) and Discourse Interpretations: Approaches and Applications (2012) published by CSP. She is co-editor of the linguistics journal Discourse and Interaction.

Address: Renata Povolná, Department of English Language and Literature, Faculty of Education, Masaryk University, Porričí 9, 603 00, Brno, Czech Republic. [e-mail: povolna@ped.muni.cz] 